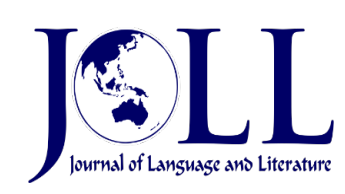

Vol. 21 No. 1, April 2021, pp. 68 - 78

DOI: 10.24071/joll.v21i1.2809

Available at https://e-journal.usd.ac.id/index.php/JOLL/index

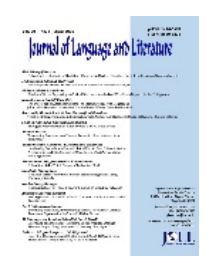

This work is licensed under a Creative Commons Attribution-ShareAlike 4.0 International License.

\title{
The Body of Woman and Woman's Rights as Portrayed in Rupi Kaur's milk and honey Based on Elaine Showalter's Gynocriticism
}

\author{
Priska Tarigan, Martha Pardede \& Siamir Marulafau \\ tpriskalangit@gmail.com, pardede.martha@yahoo.com, penyairdcm2@gmail.com \\ Deparment of English Literature, University of Sumatera Utara, INDONESIA
}

\begin{abstract}
In the time of modern writing, women writers are increasingly free in raising the theme of their writing. Women are no longer reluctant to write things related to a woman's body and it's issue. This research aims to analyze the body of women and woman's rights as portrayed in Rupi Kaur's milk and honey (2014). This research belongs to library research that applied descriptive qualitative method with gynocriticism approach. Reading and selecting data techniques were used to collect the data. 28 poems raise the theme of the body of a woman and its issue used as the data in this research. To analyze the body of woman and woman's rights in milk and honey, gynocriticism theory by Ellaine Showalter were used. The result of the analysis shows that: 1) Woman's body is described into three aspects, that is objectification of the body, owner of the body, and strength of the body. 2) There are three ways for a woman to embrace their rights. First, a woman is asked to be able to accept and acknowledge herself as she is. Second, a woman is expected to love and consider herself precious and equal to a man. Third, women must be able to help and to support other women in fighting for their rights.
\end{abstract}

Article

information

Received: 18 August 2020

Revised: 24 November 2020

Accepted: 30 November 2020

Keywords: the body of woman; woman's rights; milk and honey; gynocriticism

\section{Introduction}

In the development of woman literature, woman's writing style has changed and evolved into three phases from the Victorian period until the period of modern writing. It is the feminine, feminist, and female phases. In the feminine phase, woman writers were written under the male pseudonym. In the feminist phase, woman writers questioned the stereotype and challenged the restrictions of woman's languages. In the female phase, woman writers began to realize and place their female experience in the process of art and literature (Showalter, 1979).

Then, the female phase occurs in the time of modern writing. In the time of modern writing, women writers are increasingly free in raising the theme of their writing. They are no longer reluctant or inferior to write things related to woman's personalities or matters 
related to the physicality of women. Women writers also do not consider that writing or literary work that they make just a tool that they can use to fight against men anymore. They see literature as a medium that can be used to explain or tell about women as they are.

One of the female writers that belong to modern writing is Rupi Kaur, she is very clear in expressing her opinions about woman's issues in her works. Kaur is a talented writer who is very active in fighting for woman's rights. Her poems are mostly raising a theme about femininity and the injustice that women got from various things. She was born to a Sikh family in India on October $4^{\text {th }}, 1992$, and grew up in Canada as a Canadian citizen. Although she lived in Canada for most of her life, she never forgets about her culture of origin. Kaur's works were influenced by Sikhi culture and Woman of color issues is one of her focuses on her poem.

Her first book titled as milk and honey was published in 2014, it is a poetry collection book. The book is divided into four chapters; each chapter depicts a different theme. It tells about violence, love, abuse, and loss. Femininity serves as the main theme of the poems. All of the poems are related one to another; it has the main story to tell that is a woman's journey of life. The title of every chapter from the book represents the story such as the hurting in chapter I, the loving in chapter II, the breaking in chapter III, and the healing in chapter IV.

As for that, Kaur's poems can be classified as female phase writing. It can be seen that the female phase is a phase where women are using writing both as a tool to fight for woman's justice and also as a forum for telling women the way they are. Likewise, the Poems were written by Kaur, telling about women as they are and seem to be brave enough to show the female side that is rarely displayed in literary works. She did not hesitate to show the side of female sexuality in her poem to voice the injustice against women.

The research on gynocriticism has been discussed by Sogra Nodeh and Farideh Pourgiv (2012). This research are examined about gynocritic creates a cultural locus of female abstract identity in Adrienne Rich's A Wild Patience Has Taken Me This Far, it's describing the forces that intersect woman writer's cultural field to the social setting in which they happen. The result find out that Adrienne Rich utilizing real female feel in a female space, bring into being the symbolic weight of female awareness.

Evi Jovia Putri (2014) conducted a research on short stories wrote by women from different cultural backgrounds. The study wants to show the experiences of women from various backgrounds from five different continents through short stories. It also looks at the culture of patriarchy to underline the writings. The result shows that women writers are trying to present that being a woman was difficult, both as a young woman and as well as a middle-aged woman. It is proven by the failure of male figures in the short stories to understand the thoughts and desires of women. It also shows that patriarchal environments create an obstacle for women to be heard or to be understood.

Azadeh Nouri and Fatemeh Aziz Mohammadi (2015) analyzed the heroine's internalized consciousness which echoes in their behavior on Angela Carter's Wolf Alice. The result proves that all of the female protagonists in carter's short stories; such as The Company of Wolves, and Werewolf and mainly in Wolf Alice have similar characteristics with different conditions, in which they are represented in a very negative light with less than ideal roles. In these stories, the protagonist is a young girl who has many conflicts with love and desire. Carter attempts to encourage women to do something about this degrading representation.

Mojgan Eyvazi, Mohsen Momen, and Homa Poorkaramali (2017) analyzed three different novels wrote by Iranian female writers to show three stages of female writing development in the novels based on Eline Showalter's theory of gynocriticism (feminine, feminist and female phase). The novels' title is Hangover dawn (1995) by Fataneh Haj Sejed Javadi, My Bird (2002) by Fariba Vafi, and Don't Worry (2008) by Mahsa Moheb Ali. The study found that the three of the novels match 
Showalter's models of female writing development. It shows that Hangover dawn follows the first stage (feminine phase), Don't Worry follows the second stage (feminist phase), and My Bird comes to the third stage (female phase).

Nodeh and Pourgiv's (2012), as well as Putri (2014), are focus on analyzing the culture of a woman (the theory of woman culture) in the novel and short stories, while Nouri and Mohammadi (2015) are focus on analyzing the psychology of woman (psychoanalytical criticism) on short stories, and then Eyvazi, Momen, and Poorkaramali (2017) are analyzing the three phases of female writing development on novels based on Showalter's Gynocriticism. Gynocriticism itself has four models of analysis, that is biological criticism, linguistic criticism, psychoanalytical criticism, and the theory of woman's culture.

Then, since sexuality and the body of women are most talked in the poems and to make the research more effective, this research focuses are on the biology of woman (biological criticism) in Milk and Honey by Rupi Kaur. The objective of this research is to explain the body of the woman and the way woman embrace their rights as portrayed in milk and honey.

\section{Methodology}

The method used in this research was qualitative because the data in this study are the words and phrases instead of the numbers as statistical calculations. According to Djajasudarma (2006), Qualitative method is a procedure resulting in descriptive data in form of written text or spoken in language society. In this study, the researcher finds out the answer to the problem of the study to explain the body of the woman and the way women fight for rights as portrayed in Rupi Kaur's Milk and Honey selected poems. The result of the analysis was written in an explanatory paragraph in showing a brief description of the similarities and differences of related exploration.

The data of this study were primarily selected poems of Rupi Kaur's Milk and Honey poetry collection book. The poems was selected based on the theory of gynocriticism with biological criticism models of analysis. There are 28 poems used as the data on this research, all of the poems are contains the problem about the body of a woman and the way of woman in embracing their rights through their body. Milk and Honey was published in 2014. Kaur's milk and honey was the primary data of this research. In this paper, the primary data were the selected poems of Rupi Kaur's Milk and Honey. The writer also uses secondary data to support the primary data. The secondary data were the data from other resources such as gathering from books, articles, videos, webs, and other supporting material that relevant to this paper.

In the data selection, the writer will choose the appropriate poems that going to be analyzed. Then, the writer will also look into the secondary data, make some notes, or highlighting the related idea from other resources. All those giving notes or highlighting are important in providing the study of the analysis in this paper. In analyzing the data, the writer applied biological analysis from gynocriticism theory by Elaine Showalter (1997). A theory by Richard and Alexander (Pardede, 2017) also used to help the writer in understanding and analyzing poetry.

\section{Results and Discussion}

All of the previous studies are analyze stories and novels, most of them are focus on the theory of woman's culture and psychological criticism. This research is focused on biological criticism in analyzing poetry. The theory of woman's culture is also used to support the main models of analysis on this study. The researcher aims to find how the body of a woman is portrayed on milk and honey and what should women do to embrace their rights as a woman.

This study is analyze poems that related to the injustices received by women and the struggle that was undertaken to break out of the bonds that bind them. It is the problems faced by women related to their body and their struggle to escape from the shackles of culture and society by using their bodies. Below is the analysis of the body of woman and the struggle of woman in fighting for rights. The data were 
taken from the selected poems of the four chapters of the milk and honey, they are the hurting, the loving, the breaking, and the healing.

\section{The Body of Woman as Portrayed in milk and honey}

In this section, it is explained how the woman's body is depicted by the poetess in the poems. The woman's body was described in several different ways by the poetess, and the explanation of the description explains further below:

\section{Objectification of the Body of Woman}

This section, explains the female body is used as a sexual objectification by society, especially by men. A woman is considered as an item rather than being treated as an equal gender. Women and men have different body shapes, and it is easy for a man to be attracted to a woman's body. But this interest is only for man pleasure and to satisfy their lust, without being accompanied by the desire to care for and look after the woman. The poetess explained this through several poems. The first poem that shows the sexual objectification of woman is the following poem:

\section{she was a rose \\ in the hand of those \\ who had no intention \\ of keeping her}

In this poem, the word rose uses as a metaphor which means a woman or a beautiful woman. Besides, the third person pronoun 'she' and the possession 'her' which denotes female gender, use by the poetess to emphasizes that the rose on the line is referred to as a woman. Then, the use of past tense in the first line of the poem that says she was a rose, has a meaning that that beautiful flower has been damage. Or in other words that beautiful woman has been broken because of the hand of a man.

It can be seen that the poetess wants to say that woman is treated badly by man. In the line who have no intention of keeping her, Kaur explains that man only wants to take advantage of the beauty of women without caring about the conditions of the body that can be damaged if not treated properly. Then, the line hand of those in the poems is a metaphor that denotes a man who controls women.

A tender and soft language is used by Kaur in writing this poem. The poetess also uses the euphemism figure of speech in the line who had no intention. The use of the phrase no intention by the poetess giving a mild expression to the line, which the actual meaning is, does not care at all. It is also found in the poem that the poetess feels disappointed caused by the man's bad treatment towards a woman. It can be seen in the line had no intention of keeping her. When someone treats us badly then automatically we will feel disappointed. As well as the poetess which shows her feeling by using phrase had no intention in the poem.

$$
\begin{gathered}
\text { you } \\
\text { have been } \\
\text { taught your legs } \\
\text { are a pit stop for men } \\
\text { that need a place to rest } \\
\text { a vacant body empty enough } \\
\text { for guests but no one } \\
\text { ever comes and is } \\
\text { willing to } \\
\text { stay }
\end{gathered}
$$

This poem talks about two main problems. The first is, woman is a tool to comfort a man and the second is the powerlessness of a woman to disobey a man. First, a woman is treated as a satisfying tool of man's desires and considers not very valuable by society. It can be seen from the line your legs are a pit stop for men, the metaphor of pit stop uses by the poetess to emphasize that the men who come to her use the woman as a mere stopover. Men do not think of the woman as a precious one, they only think of her as a mere place to get rid of their fatigue. It can be known from the phrase a vacant body used in the poem. Through the line no one ever comes and is willing to stay, she shows that the men come and leave as they want.

The second, woman is taught to always obey man whatever orders are given to her, whether she likes it or not. Women have to serve male guests by using their bodies or 
being a pit stop for men. The poetess shows it in the line you have been taught. The phrase have been taught tells that the woman is made to be an obey thing who always follows the orders of men. And the use of present perfect progressive tense in the line you have been taught your legs are a pit stop for men, shows that it has been going on for a long time and still happen until now.

In the line a vacant body empty enough, there is a repetition of meaning with different words used by the poetess, they are vacant and empty. The repetition uses to emphasize the woman's condition and feeling. The woman is not in good condition; she is broken and felt empty. Moreover, there is an irony uses in this poem, that is in the line empty enough for guests but no one ever comes and is willing to stay. The use of irony in that line uses by the poetess to criticize the social behavior that assumes a woman's position is lower than man. This attitude of society discriminates against women because they are born as female.

\section{Owner of the Body of woman}

This section analyses the poems that express the owner of the female body. The poetess conveys to the reader and all women that they are entitled to themselves. Women do not have to always obey and follow what others are told to them, especially in matters relating to their bodies. A woman has complete control over her body and herself. She has the right to do what she likes and not to do what she does not like.

the next time he
points out the
hair on your legs is
growing back remind
that boy your body
is not his home
he is a guest
warn him to
never outstep
his welcome
again

This poem is made by the poetess to remind women about who is the owner of their body. Through this poem, men are also reminded by the poetess that he should not interfere with the woman about her body. A woman's body described by the poetess as a house, and the owner of the house is the woman herself. From the line, your body is not his home it says that the woman is the owner of her own body, and a woman's body is not the man's home. Then, in the line he is a guest, it says that man just a guest who has no right to determine or making decisions on a woman's body. Through the line remind that boy and warn him to never outstep his welcome the poetess wants to encourage women to dare, to be assertive to the man who wants to act like masters over herself. It says by the poetess that woman should reprimand man and reminded him that he is just a guest who could be evicted at any time.

Through the line he points out the hair on your legs is growing back, the poetess tells that man often do not like woman's bodies that are overgrown with lots of hair. It says that the hair would bother man and they want women to get rid of it. The phrase he points out and the line outstep his welcome is also express the man's superiority towards woman. It can be known that men think that woman's body is under their control. Men are accustomed to commanding women to do something that they want, and it makes them feel that they are also entitled to the body of a woman. But, this poem is made to remind men that they are not entitled to the body of a woman, it is fully entitled to the woman itself.

There is a metaphor used by the poetess in this poem. It found in the line is not his home and he is a guest. The home symbolizes a woman's body and the guest symbolizes a man. The use of metaphor in this poem is to warn the reader that the position of man in freeing the body of a woman. A man is just a guest in a woman's body, he should not intervene in the woman's privacy. The woman itself is the one who is entitled to control her body, whether a man likes it or not.

\section{Strength of the Body of Woman}

This section explains the strength of the female body. It is about the uniqueness of the female body. It seems weak from the outside but it is strong enough inside. It tells about the 
strength of females and what makes them strong in facing the problem that comes unfinished. Foucault (1995) said that besides the visible parts, the human body also contains the whole soul both the mind and feeling for what is invisible to the eyes of human instinct. So, this section raises a theme about the strength of women, both physical and also psychological.

Physically woman is weaker than a man, but there are other strengths of a woman that makes a woman can be stronger than a man. In milk and honey poems, a woman's strength mostly is psychological. A woman cannot beat a man in the physical strength, but a woman is superior if it comes to heart and soul. Women are unique in terms of power; they did not use violence to defeat others. By love, a woman will make others turn their anger into affection. It tells in the poem below.

\section{to be \\ Soft \\ Is \\ To be \\ Powerful}

The poem above uses contrast to strengthen the meaning of the poem and the message that want to convey by the poetess. The contrast is found in the word soft and powerful. The meaning of this poem is a woman with her unique power. Women can be strong by being soft and tender. Generally, soft is usually connoted as weak and far from strong. However, in this poem, it says that the softness of women both physical and also mental is the greatest strength possessed by women. To be soft is not always to be weak. It is precise with that gentleness that women can break down the hardness of the hearts of their haters.

This poem tells that woman is a creature that is strong because of her softness, to be soft is to be powerful. Even though physically woman is weaker, but from her soul woman is not inferior to man. Woman has enormous strength stored in her heart and soul. With the tenderness that she has, a woman can do great things that cannot be done by a man. It also tells that woman should not feel inferior to a man just because of her physical weakness. To become a doughty woman does not need strong bones and muscles or a big and tall body. A woman can be strong with her kindness. It can soften the hardness of her hatred's heart and turn their cruelty to become affection and wish to protect.

This is a simple and one of the shortest poems in milk and honey. The words in this poem are smooth and soft but have a strong meaning. The meaning of the poem is seen in the lines of the poem, short but powerful. It shows the power with the softness of a woman.

Through another poem, the poetess says that the strength and the power of women are not in their physical beauty, but it is in their determination beyond anything. It shows by the poetess in the poem below:

\section{$i$ want to apologize to all the women i have called pretty \\ before i've called them intelligent or brave i am sorry i made it sound as though something as simple as what you're born with \\ is the most you have to be proud of when your spirit has crushed mountains from now on $i$ will say things like you are resilient or you are extraordinary not because i don't think you're pretty but because you are so much more than that}

Just like the three previous poems, this poem also raises the theme of female body strength. Specifically, it shows that women's strength does not lie in their physical, but it is in their spirit and soul, your spirit has crushed mountains. Through this line, the poetess shows that women's souls are extraordinary so it can crush mountains. Mountains here are not mountains in the literal meaning. It means the hatred towards woman which has been going on for a long time in society, and woman has crushed it. Women can destroy the hatred because of their spirit is strong, so they can turn it into affection and love.

The phrases you are resilient and you are extraordinary, highlighted by the poetess to emphasize that women are far more powerful 
than just beautiful. Women are creatures that are resilient in their gentleness and extraordinary in their simplicity. Their strength comes from their heart and soul which are not easily broken even though they have experienced much suffering. Through the line $i$ want to apologize to all women $i$ have called pretty before $i$ called them intelligent or brave..., the poetess emphasizes that woman is not just a soulless flesh who only has a body to praise. Women are more than just pretty or beautiful, and it clearly says by the poetess in the line ...you are so much more than that.

In this section, it is explained how the struggle and the movement carried out by women to embrace their rights. The movement to support each other and encourage women to love themselves more is the thing most delivered by Kaur in her poem. The analysis of how to embrace woman's rights is further explained below:

\section{Self-acceptance}

This section analyzes poems that express the woman's self-acceptance. The poetess conveys to the reader especially women that they should accept themselves under any circumstances. No matter how they look and how their appearance, they must be able to accept it in pride and with an open heart. To reclaim the rights that are taken from them, the first thing women must do is to accept themselves first.

\section{accept yourself \\ as you were designed}

The poem above writes by the poetess to convince women that they are beautiful as they are. Wanting to accept and be grateful for what is in them both physically and psychologically is the first step for women to get out of the circle that holds them. Recognizing and accepting what they have with an open heart is very important. It will make women easier to love and respect themselves.

The poetess in her poem says that to be a complete woman, a woman does not have to have a smooth and beautiful body. The scars on a woman's body are proof that they are tough women, which is a picture that the woman is soft but also strong. It is precisely the ability to endure and the expertise to heal these wounds that makes a woman whole and complete. As written in the poem below:

i like the way the stretch marks
on my thighs look human and
that we're so soft yet
rough and jungle wild
when we need to be
i love that about us
how capable we are of feeling
how unafraid we are of breaking
and tend to our wounds with grace
just being a woman
calling myself
a woman
makes me utterly whole
and complete

This poem tells about self-acceptance. Accepting and seeing all of the flows on ourselves as beautiful things. Can see a flaw as a doon, $i$ love that about us. Women often feel that the scars on their bodies are blemishes that should not be present. A lot of women crave a smooth and beautiful body without a scar found on their bodies. Because of this desire, women end up doing various methods that hurt themselves. Therefore, through this poem, the poetess shows that the most important thing for a woman is to accept herself as she is. The poetess clearly states that in the poem, in the line i like the way the stretch marks on my thighs look human. The line tells us that being human doesn't mean that we cannot have any scars on our bodies. Instead, wounds and scars would make us more human.

Through the poem, the poetess wants to say that not having smooth skin is a very normal thing for a woman. The line we're so soft shows that woman has a slender body so they can get hurts easily. However, besides being easily injured women are also gifted with the ability to care for themselves and recover from those injuries, tend to our wounds with grace.

The line how unafraid we are of breaking, says that being a whole woman is not by 
having no injuries at all. But by accepting the wounds and caring it in the tender will be the evidence of beauty and tenderness of a woman. The line just being a woman, calling myself a woman, also shows that woman doesn't need to be flawless. Just be herself is more than enough to be a woman and to be a whole human, utterly whole and complete.

Through the poem, it can be known that thee poetess wants to encourage women to be able to see herself as a precious thing. The line rough and jungle wild when we need to be told that woman has huge potential other than her beautiful physicality. Rather than crave a beautiful body, women should be proud of their ability to survive in any situation.

The language used by the poetess in this poem is soft and beautiful. She wants to touch the reader's heart with the poem. The phrases and lines such as look human, so soft, how capable, how unafraid, tend our wounds with grace, being a woman, and whole and complete give the readers a positive vibe. There is also a contrast in the line so soft yet rough. The use of contrast here aims to convince women that they are precious, so they have to proud and accept themselves no matter how.

\section{Self-loving}

This section analyzes poems that express the efforts made by women to embrace their rights by loving themselves. The poetess, through her poems, says that before a woman demands other people to respect and love her, she must be able to love herself first. Because by loving herself, the woman will give an example of how others should behave to her. If a person cannot love herself, how can others love her and treat her well? This contains in the poems below:

\section{how you love yourself is how you teach others to love you}

This poem has a very deep meaning and also has firmness in conveying the message. The poem reminds women to love themselves so others will love them too. Through the poem, the poetess also tells women that they have a great responsibility for the treatment of others. If a woman is always feeling inferior and considers herself less valuable than a man, then others will also treat her in a bad way. But, when a woman appreciates and loves herself and shows others that she is precious, others will also treat her as such.

The line you teach others to love you means that a woman herself has to make others love them. The poetess clearly says that others will see how a woman treats herself. If a woman even cannot love herself how others will love her. So, they should be able to set a good example for others in treating them. And that will only happen if they love themselves first.

In this poem, the direct language is used by the poetess. She also chooses words that are simple and easy to understand. By choosing simple diction and does not use complicated language styles, makes this poem looks like advice to all readers, especially women. When it is viewed from the poetical technique of poetry, this poem is relatively short and also simple. But the simplicity of the poem does not reduce the power of the poem in conveying its meaning.

\section{Woman for woman}

The analysis at this point is about women who support each other, or it can be said as a woman for a woman. To be equal to men and get the rights that should be theirs, a woman must be able to support each other. Woman's struggle will never succeed if among women there is still a sense of envy and a desire to topple each other. In a study conducted by Workplace Bullying in 2010, it was found that the level of bullying by woman in the workplace was very high, reaching $71 \%$ and more than $90 \%$ of the targets were women. From this research, it is known that women often see other women as competitors rather than as sisters who must be supported. Women will be jealous of the success achieved by other women, and they prefer to pout other women's success rather than admit it. The poetess also conveys this in the poem below:

\author{
what terrifies me most is how we \\ foam at the mouth with envy \\ when others succeed \\ but sigh in relief
}


when they are failing

our struggle to

celebrate each other is

what's proven most difficult

in being human

Through foam at the mouth with envy, the poetess says that a woman can be greatly tormented because of envy when they see another woman more successful than her. For some women, the success of other women means a setback for her. Then, instead of acknowledging and appreciating the success of other women, a woman often prefers to drop it and hope that success will end quickly.

The line but sigh in relief when they are failing, and celebrate each other is what's proven most difficult proves that many women still have difficulties in supporting other women. They can easily accept the success achieved by men but underestimate the results of women's efforts (narasi.tv: 2019). Women will also feel happy when they are considered better than other women, especially if they were compared by man. The poetess then criticizes this concept with the poem she wrote below:

you tell me
i am not like most girls
and learn to kiss me with your eyes closed
something about the phrase-something
about
how i have to be unlike the women
i call sisters in order to be wanted
makes me want to spit your tongue out
like i am supposed to be proud you picked
me
as if i should be relieved you think
i am better than them

The poem above is addressed by the poetess to men who often compare one woman to another. It clearly says in the line you tell me $i$ am not like most girls. In this poem, the poetess criticizes the attitude of men who often discriminate between a woman to another, and this is a wrong and disgusting attitude. The poetess uses the phrases something about and spit your tongue out, to express her dislike of the attitudes and words conveys by men to compare women.
In addition to criticizing the attitudes of men towards women, this poem also has another message addressed to women. The message is to remind women not to be persuaded by the flattery and praise that men are giving to them. They should know where are the words that can support them and where is the one which only wants their falling.

This poem expresses Kaur's hope that women not to trust what men said and thought that they were different and better than other women. In the line like i am supposed to be proud you pick me and as if $i$ should be relieved you think i am better than them, the poetess says that woman should not differentiate herself from other women. Women must help and support one another so that they will be able to get up and get their rights.

The poetess also reminds women that other women are not enemies they have to be defeated but sisters are obliged to support and embrace.

\section{other women's bodies \\ are not our battlegrounds}

In this poem, the poetess reminds us that a woman's body is not a battlefield for another woman. The word battlegrounds are used by the poetess to emphasize the message she wants to convey. It is known that women often see other women as a barrier that must be destroyed. Then through this poem, women are reminded that that view is wrong. A woman is not a barrier for another woman, not even a shackled that has to get rid of, not our battlegrounds. It can be seen that the poetess hopes that women can support each other and work together to fight for their rights. This is also seen in the poem below:

\section{we all move forward when we recognize how resilient and striking the women around us are}

The poem above shows that by acknowledging and supporting the success of other women, a woman will also move forward and achieve her success. Accepting the success of women around them is not a setback for a woman, rather a way to be able to rise together 
against the stigma that has been difficult for women.

In another poem, the poetess also says that when a woman is amazed and praises other women the amazing itself is her.

\author{
for you to see beauty here \\ does not mean \\ there is beauty in me \\ it means there is beauty rooted \\ so deep within you \\ you can't help but \\ see it everywhere
}

The line it means there is beauty rooted so deep within you shows that what women see in others is a reflection of her own. It is like seeing through a mirror. By being able to see other women in a positive perspective, the woman must have become someone extraordinary first. Therefore, from this poem, the poetess says that women will succeed in fighting for their rights when they want to support each other and recognize the greatness of women around them.

It can be concluded that to fight for their rights, women no longer have to criticize and fight against men who act badly on women. Instead, the struggle can be carried out by women by raising the dignity of women in society. Women can fight for their rights nobly and elegantly, that is by recognizing and supporting each other. Woman for woman is an act where women stop seeing other women as competitors who must be defeated but begin to see them as sisters that they must embrace. Thus, women will be strong and can rise together as a gender that equal to men, they will no longer be ostracized but rather they will be respected as men are respected.

\section{Conclusion}

Based on the analyzed data, the writer then makes some conclusions about the gynocriticism analysis on Rupi Kaur's milk and honey, the conclusion is as follows:

This research concludes that the body of a woman in milk and honey is portrayed in three aspects; objectification of the body, owner of the body, and strength of the body. There are also three ways offered by the poetess for woman to embrace their rights, they are, selfaccepting, self-loving, and woman for woman.

In the objectification of the body, Kaur shows how the woman's body is used as a tool to satisfy man's desire. It is also said that woman's body is liked, but its natural system of the body like menstruation is considered as a taboo in society. In the owner of the body, Kaur explains that the master of a woman's body is the woman herself; a woman has the full right to do what she wants and to not do what she does not want with her body. And in the strength of the body, it says that even a woman's body seem weak in the outside, but women cannot be defeated easily because they have huge power in the inside. Women's powers lie not in their physical but in the soul and heart.

In the self-accepting, it says that the way women could get their rights is to accept themselves as they are and be proud of what they have. In the self-loving, it says woman should loving herself as is she is her soulmate. And in the woman for woman, it says that after a woman accepts and loves herself no matter what the circumstances, afterward women must also be able to acknowledge and support other women. In this third point, it says that women have to support other women in fighting for their rights together.

\section{References}

Dahya, Asha. (2016). Girl on a Mission: Poet \& Activist Rupi Kaur on Pushing Social Boundaries for The Sake of Intersectional Feminism retrieved from www.girltalkhq.com on September 3, 2019

Djajasudarma. (2010). Metode Linguistik: Ancangan Metode Penelitian dan Kajian. Bandung: Reflicaa Aditama.

Eagleton, Terry. (2009): Literary Theory: An Introduction. Minneapolis: Minnesota Press. 
Erna A. (2019). Female Body and Identity as Represented in Rupi Kaur's Poetry Milk and Honey. Thesis. Faculty of Cultural Study. Muhammadiyah University of Surabaya: Surabaya.

Eyvazi, Mojgan, Mohsen Momen, \& Homa Poorkaramali. (2017). A Study of Selected Works of Iranian Female Novelists Based on Elaine Showalter's Gynocriticism. International Journal of Applied Linguistics \& Literature, 6(4), 1-7. Retieved from https://www.journals.aiac.org.au/index. php/IJALEL/article/view/3289

Gray, Emma. (2015). The Removal of Rupi Kaur's Instagram Photos Shows How Terrified We Are of Periods retrieved from www.huffpost.com on September 3, 2019.

Irena V. (2012). Gynocriticism and Binary Opposition in Who Said It Was Simple and Women Speaks by Audre Lorde. Thesis. Faculty of Cultural Study. Bina Nusantara University: Jakarta.

Jacobus, Mary. (2012). Women Writing and Writing about Women. Routledge: Abingdon.

Kaur, Rupi. (2014). Milk and Honey. Canada: Andrews McMeel Publishing.

Kaur, Rupi. (2016). Frequently ask questions. Retrieved September 28, 2019, from Rupi Kaur's website: https://rupikaur.com/ faq/

Neuman, W. L. (1997). Social Research Methods Qualitative and Quantitative Approach 3rd Edition. Boston: Pearson Education.Inc

Nodeh, S., \& Farideh Pourgiv. (2012). Showalter's Gynocriticism: Female Wild Zone of Experience in Adrienne Rich's "A Wild Patience Has Taken Me This Far." The Criterion an International Journal in English. III(IV): 1-12. Retrieved from http://www.thecriterion.com/V3/n4/Nodeh.pdf
Nouri, A., \& Fatemeh Aziz Mohammadi. (2015). A Study of Carter's "Wolf Alice" based on Showalter's Gynocriticism. International Letters of Social and Humanistic Sciences. 48(1): 1-8. Retrieved from https://doi.org/10.18052/www.scipress. com/ILSHS.48.1

Pardede, Martha. (2016). Literature and Introductory Material. Medan: USUpress.

Pardede, Martha. (2017). An Introduction To Poetry. Medan: USUpress.

Putri, Evi Jovita. (2014). Female Experiences In Different Cultural Backgrounds: Gynocriticism On Short Stories Of Five Continents. Vivid Journal of Language and Literature, 2(1), 1-10. Retrieved from

http://jurnalvivid.fib.unand.ac.id/inde x.php/vivid/article/view/20

Showalter, Elaine. (1977). A Literature of Their Own: British Women Novelists from Bronte to Lessing. Princeton: Princeton University Press.

Showalter, Elaine. (1993). American Gynocriticism. The American Literary History Journal. 5(1), 111-128.

Showalter, Elaine. (1979). Toward a Feminist Poetic, “Women's Writing and Writing About Women." London: Croom Helm.

Synnott, Anthony. (2002). The Body Social: Symbolism, Self, and Society. Abingdon: Routledge 